\title{
Effect of Fraxiparine, a type of low molecular weight heparin, on the invasion and metastasis of lung adenocarcinoma A549 cells
}

\author{
CHUAN-JIANG YU, SU-JUAN YE, ZHI-HUA FENG, WEN-JING OU, XI-KUN ZHOU, \\ LING-DONG LI, YONG-QIU MAO, WEN ZHU and YU-QUAN WEI
}

State Key Laboratory of Biotherapy and Cancer Center, West China Hospital, Sichuan University, 610041 Sichuan, P.R. China

Received March 16, 2010; Accepted May 22, 2010

DOI: 10.3892/ol_00000132

\begin{abstract}
Lung cancer is one of the most highly malignant tumors, and a significant threat to human health. Lung cancer patients often exhibit tumor cell invasion and metastasis, which often render current treatments ineffective. Recently, the beneficial effects of low molecular weight heparin (LMWH) on cancer metastasis were reported in pre-clinical research studies. LMWH may be a potential drug for cancer therapy. However, the mechanism of LMWH on the invasion and metastasis of cancer has yet to be determined. This study investigated the effects of Fraxiparine on the proliferation, invasion and metastasis of the human lung adenocarcinoma A549 cell line. MTT assay and flow cytometry showed that Fraxiparine slightly inhibited the cell viability dose- and timedependently, but did not arrest the A549 cells in the G1 phase nor induce early apoptosis. The transwell chamber assay showed that Fraxiparine significantly suppressed the invasion and migration of the A549 cells in vitro. Fraxiparine also markedly inhibited the adhesion of the A549 cells to Matrigel. The RT-PCR assay demonstrated that the reduction in invasion and metastasis may be related to the up-regulation of $\mathrm{nm} 23-\mathrm{H} 1$ and the down-regulation of the heparanase expression. Moreover, the RT-PCR assay and Western blot analysis demonstrated that down-regulation of the expression of integrin $\beta 1$ and $\beta 3$, as well as that of matrix metalloproteinase- 2 and -9 may be responsible for the inhibition of the invasion and metastasis of A549 cells by Fraxiparine.
\end{abstract}

\section{Introduction}

Lung cancer is the leading cause of cancer-related mortality in both men and women worldwide (1). The strong invasive and metastatic characteristics of lung tumor cells are responsible

Correspondence to: Professor Wen Zhu, State Key Laboratory of Biotherapy, West China Hospital, Sichuan University, No. 1 Keyuan 4th Road, Gaopeng Street, High Technological Development Zone, Chengdu, 610041 Sichuan, P.R. China

E-mail: zwjulia@163.com

Key words: lung cancer, low molecular weight heparin, fraxiparine, invasion, metastasis for their relatively high malignancy. Heparins are glycosaminoglycans that play a variety of cellular and plasmatic roles (2). Unfractionated heparin (UFH) and low molecular weight heparin (LMWH) prevent the process of blood coagulation in clinical therapy by activating antithrombin III and inhibiting activated coagulation factors X and II (3). Recently, UFH was largely replaced by LMWH in clinical use since LMWH has a longer half-life and less bleeding (4).

Besides their anticoagulant effects, a wide variety of biological activities of LMWH have been identified. Previous clinical studies strongly suggest that LMWH, used to treat venous thromboembolism in patients with cancer such as lung (5-7), breast (8,9), brain (10) and other advanced cancers (11-13), delays tumor progression and prolongs survival. Experimental evidence from animal models strongly indicates that LMWH is an efficient inhibitor of cancer metastasis (14-16). The anticancer activity of LMWH may be correlated with anti-metastasis activity. However, the effect and precise mechanism of LMWH on the invasion and metastasis of lung cancer have yet to be determined.

Fraxiparine (nadroparin calcium), a low molecular weight heparin, is a heterogeneous combination of sulphated polysaccharide glycosaminoglycan chains. It is used to treat deep vein thrombosis in the clinic. In this study, intervention was conducted with regards to the invasion and metastasis of A549 cells with Fraxiparine and the alteration of cell invasion, migration and adhesion status was observed. Concomitantly, the change in cell viability, cell cycle progression and the apoptotic status of A549 cells treated with Fraxiparine was noted. Furthermore, the expression of two tumor invasionand metastasis-associated genes (nm23-H1 and heparanase) was detected at the mRNA level. The expression of four tumor invasion- and metastasis-associated genes, i.e., integrin $\beta 1$ and $\beta 3$, as well as matrix metalloproteinase (MMP)-2 and -9, was further examined at the protein and mRNA levels.

\section{Materials and methods}

Materials. The A549 cell line was purchased from the American Type Culture Collection (USA). The cell culture medium and reagents were obtained from Gibco Laboratories (USA). Fraxiparine (LMWH) was purchased from Glaxosmithkline (UK). 3-(4,5-Dimethylthiazol-2-yl)-2,5-diphenyl tetrazolium bromide (MTT) and propidium iodide (PI) were products of 
Sigma (USA). Annexin V-FITC Detection kit was purchased from Keygen (China). Matrigel and transwell chambers were purchased from Becton-Dickinson (USA), and the TRIzol reagent was obtained from Invitrogen (USA). The reverse transcription kit was purchased from Tiangene (China), and the PCR kit was purchased from Sinobio (China). The BCA Protein assay kit was a product of Thermo (USA), and the PVDF membrane was purchased from Millipore (USA). The rabbit polyclonal anti-GAPDH was obtained from Trevigen (USA), and the mouse monoclonal anti-integrin $\beta 1$ and $\beta 3$ were purchased from Santa Cruz Biotechnology (USA). Rabbit monoclonal anti-MMP-2 and anti-MMP-9 were purchased from Abcam (USA). Enhanced chemiluminescence reagents were obtained from Amersham Pharmacia Biotech (USA).

Cell viability assay. A549 cells were incubated in RPMI-1640 containing 10\% FBS (fetal bovine serum) and $1 \%$ antibiotics at $37^{\circ} \mathrm{C}$ in a humidified atmosphere containing $5 \% \mathrm{CO}_{2}$. The effect of Fraxiparine on the cell viability of A549 cells was determined using the MTT assay. A549 cells (3,000/well) were seeded into a 96-well plate and incubated in a culture medium containing Fraxiparine with a particular concentration for 24, 48 and $72 \mathrm{~h}$, respectively. Subsequently, the medium was replaced with $200 \mu \mathrm{l}$ of fresh medium, and $20 \mu \mathrm{l}$ of sterile filtered MTT $(5 \mathrm{mg} / \mathrm{ml})$ stock solution in phosphate-buffered saline (PBS) was added to each well. After $4 \mathrm{~h}$, unreacted dye was removed by aspiration. The formazan crystals were dissolved in $150 \mu \mathrm{l}$ DMSO per well and measured spectrophotometrically in a microplate reader (Bio-Rad, USA) at a wavelength of $490 \mathrm{~nm}$. The cell survival was expressed as: cell viability $=\left(\mathrm{OD}_{\text {treated }} / \mathrm{OD}_{\text {control }}\right) \times 100 \%$.

Cell cycle distribution and cell apoptosis ratio assay. A549 cells $\left(1.5 \times 10^{5}\right)$ in $2 \mathrm{ml}$ were plated in 6-well plates and incubated for $24 \mathrm{~h}$. The following day, the primary medium was replaced with medium containing the indicated concentrations of Fraxiparine for a 24-h incubation. At the end of the second 24-h incubation, both the adherent cell layer, which was trypsinized, and the cells floating in the medium were collected. Cells $\left(1 \times 10^{6}\right)$ were washed. For cell cycle analysis, the cells were incubated with $2 \mu \mathrm{g} / \mathrm{ml}$ of RNase A in PBS $(200 \mu \mathrm{l})$ and PI $(0.1 \mu \mathrm{g} / \mathrm{ml})$ in $0.6 \%$ Nonidet P-40 on ice for $30 \mathrm{~min}$. The DNA contents of the samples were immediately measured using flow cytometry (Becton-Dickinson). The apoptosis assay was carried out as recommended by the manufacturer of the Annexin V-FITC Detection kit. Data concerning the cell cycle phase distribution and apoptosis were determined using CellQuest software (Becton-Dickinson).

Determination of invasion and migration. Cell invasion and migration were determined with or without Matrigelcoated transwell chambers. Filters in the upper compartment were loaded with $100 \mu \mathrm{l}$ serum-free RPMI-1640 containing $5 \times 10^{4}$ cells incubated with Fraxiparine, and the lower compartment was filled with RPMI-1640 containing 10\% FBS. The chamber was then cultivated in $5 \% \mathrm{CO}_{2}$ at $37^{\circ} \mathrm{C}$ for $24 \mathrm{~h}$. The Matrigel and cells in the upper chamber were removed, and the attached cells in the lower section were stained with $0.1 \%$ crystal violet. These cells were then counted and photographed under a light microscope.

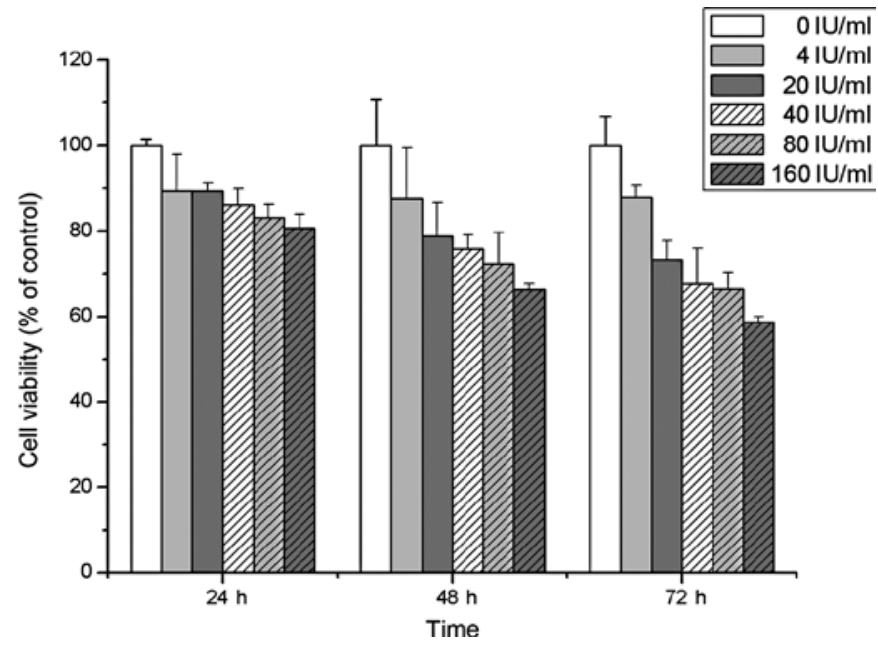

Figure 1. Effect of Fraxiparine on A549 cell viability. A549 cells were seeded into 96-well plates and cultured with different concentrations of Fraxiparine in triplicates. Cell viability was evaluated by the MTT assay. Data show the mean \pm SD from three independent experiments.

Cell adhesion assay. Each well of 96-well plates was coated with Matrigel for $1 \mathrm{~h}$ at $37^{\circ} \mathrm{C}$. The plates were rinsed with PBS and blocked with $1 \%$ BSA for $1 \mathrm{~h}$ at $37^{\circ} \mathrm{C}$. For the $24-\mathrm{h}$ treatment with Fraxiparine, cells were harvested with trypsin, added to the wells at $1 \times 10^{4}$ cells/well and allowed to adhere for $1 \mathrm{~h}$ at $37^{\circ} \mathrm{C}$. Non-adherent cells were removed by gentle washing, and the number of attached cells was measured using the MTT assay as described for the cell viability assay.

Reverse transcription-polymerase chain reaction (RT-PCR) analysis. The mRNA expression levels of heparanase, $n m 23-H 1$, integrin $\beta 1$ and $-\beta 3$, and MMP- 2 and -9 in the A549 cells treated with Fraxiparine were evaluated using RT-PCR analysis. The A549 cells were incubated in a culture medium containing Fraxiparine with a particular concentration. Total RNA was extracted from the A549 cells using TRIzol reagent according to the manufacturer's protocol. Total RNA $(1 \mu \mathrm{g})$ was reverse-transcribed, and PCR was performed with genespecific primers. The PCR products were electrophoresed in $1 \%$ agarose gel containing Golden View in 1X TAE buffer.

Western blot analysis. The protein expression levels of integrin $\beta 1$ and $\beta 3$, and MMP-2 and -9 in A549 cells treated with Fraxiparine were examined by Western blot analysis. A549 cells were incubated in a culture medium containing Fraxiparine with a particular concentration for $24 \mathrm{~h}$, harvested in RIPA buffer $(150 \mathrm{mM} \mathrm{NaCl}, 50 \mathrm{mM}$ Tris, $\mathrm{pH}$ 8.0, $1 \%$ Triton X-100, $0.5 \%$ sodium deoxycholate, $0.1 \%$ SDS supplemented with protease inhibitors and $1 \mathrm{mM}$ phenylmethylsulfonyl fluoride) and homogenized. The whole cell lysates were centrifuged at $12,000 \mathrm{x} \mathrm{g}$ for $10 \mathrm{~min}$ at $4^{\circ} \mathrm{C}$, and the protein concentrations were determined by the BCA protein quantification assay. Samples were boiled in SDS sample buffer, and an equal amount of total proteins was loaded on each lane and separated by SDS-PAGE. The separated proteins were transferred to a polyvinylidene difluoride membrane and probed with primary antibodies and horseradish peroxidase-conjugated secondary 
A

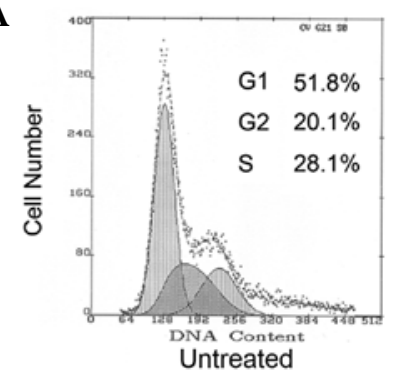

B

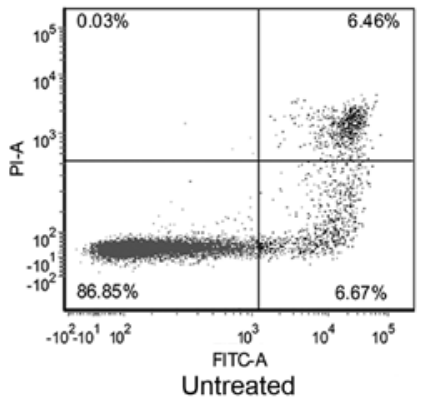

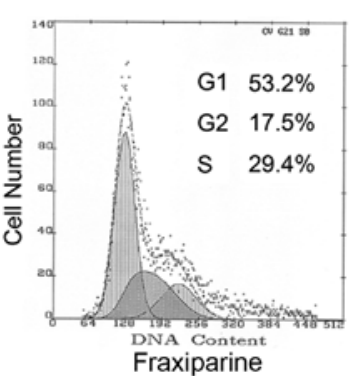

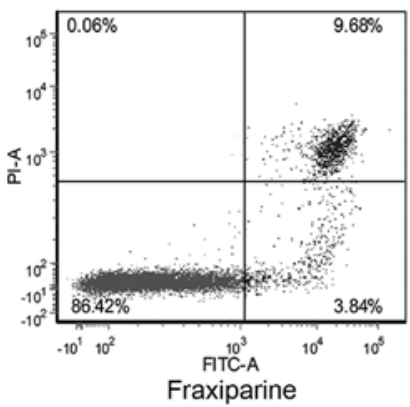

Figure 2. Effect of Fraxiparine on cell cycle progression and apoptosis. A549 cells were seeded into 6-well plates and cultured for $24 \mathrm{~h}$. The cells were incubated in the medium or medium containing $20 \mathrm{IU} / \mathrm{ml}$ of Fraxiparine for $24 \mathrm{~h}$. (A) The collected cells were stained with PI. Distribution of the cell cycle phase was quantified by flow cytometry. (B) The collected cells were stained with Annexin V-FITC and PI and analyzed by flow cytometry. Viable cells excluded Annexin V-FITC and PI. Early apoptotic cells were Annexin V-FITC-positive and PI-negative, whereas cells that were no longer viable due to apoptotic or necrotic cell death were positively stained by both Annexin V and PI.

antibodies. Immune complexes were visualized with enhanced chemiluminescence reagents.

Statistics. The values yielded are the mean \pm SEM. The significance of difference between the experimental groups and controls was assessed by the Student's t-test. $\mathrm{P}<0.05$ indicates a significant difference.

\section{Results}

Effect of Fraxiparine on cell viability, cell cycle progression and apoptosis. This study examined the cell viability of A549 cells treated with Fraxiparine at different time points (24, 48 and $72 \mathrm{~h}$ ) using the MTT assay. A slight inhibition of cell viability was observed following treatment with various concentrations of Fraxiparine in a dose- and time-dependent manner (Fig. 1). Furthermore, the effects of Fraxiparine on cell cycle progression and the apoptotic status of A549 cells were investigated. Treatment of A549 cells with Fraxiparine (20 IU/ml) for $24 \mathrm{~h}$ neither arrested cells in the $\mathrm{G} 1$ phase nor induced early apoptosis when compared to the control (Fig. 2). Similar results were obtained for longer (48 and $72 \mathrm{~h}$ ) or higher concentration $(80 \mathrm{IU} / \mathrm{ml})$ treatments (data not shown).

Effect of Fraxiparine on A549 cell invasion, migration and adhesion. Invasion is critical for the formation of metastasis and the spreading of cancer in vivo. To examine whether Fraxiparine altered the invasion status of A549 cells, Matrigelcoated transwell chambers were used. Cell invasion was
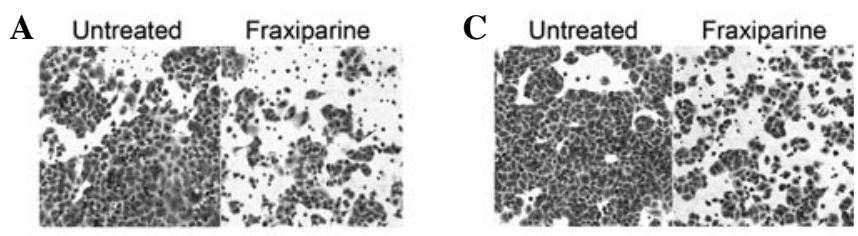

B

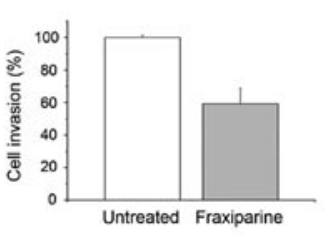

D

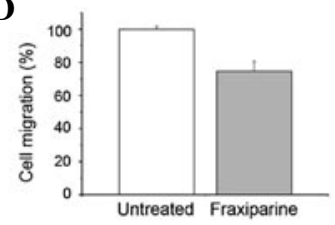

$\mathbf{E}$

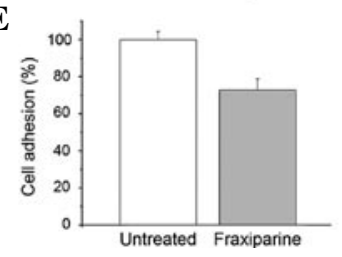

Figure 3. Effect of Fraxiparine on A549 cell invasion, migration and adhesion. (A and B) A549 cells treated with $20 \mathrm{IU} / \mathrm{ml}$ of Fraxiparine or not were placed into transwell cell culture chambers coated with Matrigel. Cells that penetrated through the Matrigel to the lower surface of the filters were stained with crystal violet and photographed under a light microscope at a magnification of x100. (C and D) A549 cells treated with $20 \mathrm{IU} / \mathrm{ml}$ of Fraxiparine or not were seeded into transwell cell culture chambers on membrane filters not coated with Matrigel. Cells that penetrated through the membrane to the lower surface of the filters were stained with crystal violet and photographed under a light microscope at a magnification of x100. (E) After a 24-h treatment with Fraxiparine $(20 \mathrm{IU} / \mathrm{ml})$, cells were plated on 96 -well plates, coated with Matrigel and cultured for $60 \mathrm{~min}$. Non-adherent cells were then removed, and adherent cells were measured using the MTT assay. quantified as the number of cells that traversed the chamber in $24 \mathrm{~h}$. The result showed that Fraxiparine caused a decrease in A549 cell invasion (Fig. 3A). Quantification of the cells in the chamber showed a decrease of $\sim 40 \%$ at $20 \mathrm{IU} / \mathrm{ml}$ of Fraxiparine (Fig. 3B). Moreover, less migration was observed in the Fraxiparine-treated A549 cells (Fig. 3C). Quantitatively, this amounted to a $25 \%$ decrease in the number of cells that traversed the transwell (Fig. 3D). Cell-matrix interaction is crucial for cancer cell invasion since this interaction affects tumor cell locomotion and the proteinase expression. Our result showed that Fraxiparine inhibited the adhesion of the A549 cells to Matrigel (Fig. 3E), and the inhibition rate reached $27 \%$. Additionally, the inhibition ratio of Fraxiparine at a concentration of $80 \mathrm{IU} / \mathrm{ml}$ on the invasion, migration and adhesion of A549 cells was found to be higher than that at the concentration of $20 \mathrm{IU} / \mathrm{ml}$ (data not shown).

Effect of Fraxiparine on the expression levels of nm23-H1, heparanase, integrin $\beta 1$, integrin $\beta 3, M M P-2$ and MMP-9. To investigate the molecular mechanism of Fraxiparine on the invasion and metastasis of A549 cells, we first examined mRNA expression levels of heparanase, $\mathrm{nm} 23-\mathrm{H} 1$, integrin $\beta 1$ and $\beta 3$, and MMP-2 and -9 in A549 cells treated with Fraxiparine using RT-PCR. The RT-PCR analysis showed that the expression level of nm23-H1 increased and the levels of heparanase, integrin $\beta 1$ and $\beta 3$, and MMP-2 and -9 decreased in the A549 cells treated with Fraxiparine (20 IU/ml) for $24 \mathrm{~h}$ (Fig. 4A).

Furthermore, the protein expression levels of integrin $\beta 1$ and $\beta 3$, and MMP-2 and -9 in the A549 cells treated 


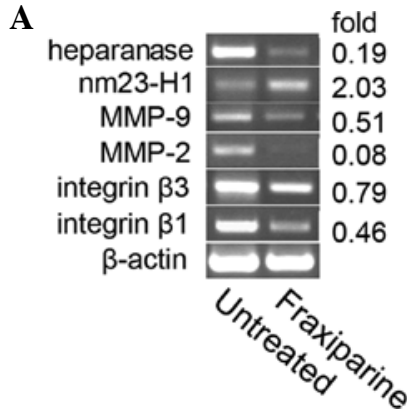

B

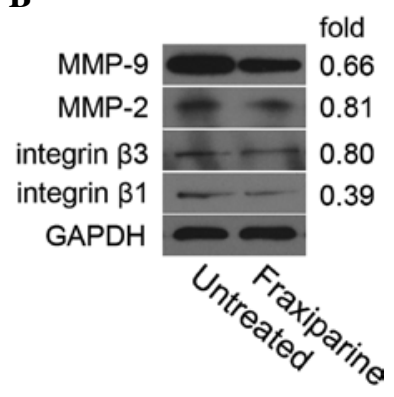

Figure 4. Effect of Fraxiparine on the expression level of nm23-H1, heparanase, integrin $\beta 1, \beta 3$, MMP-2 and -9 in A549 cells. (A) A549 cells were incubated with medium or medium containing $20 \mathrm{IU} / \mathrm{ml}$ of Fraxiparine for $24 \mathrm{~h}$. The total RNA of the control and study groups were then extracted using TRIzol reagent. The genes of $\beta$-actin, $\mathrm{nm} 23-\mathrm{H} 1$, heparanase, integrin $\beta 1, \beta 3$, MMP- 2 and -9 were amplified. The PCR products were electrophoresed in $1 \%$ agarose gel containing $1 \mathrm{X}$ TAE buffer. The optical densities were measured and standardized with the density of the $\beta$-actin gene. (B) A549 cells were incubated with medium or medium containing $20 \mathrm{IU} / \mathrm{ml}$ of Fraxiparine for $24 \mathrm{~h}$. Proteins were then isolated and examined using Western blot analysis. The densities of the bands were calculated and balanced by the expression of GAPDH.

with Fraxiparine were analyzed by Western blotting. The results indicated that the levels of integrin $\beta 1$ and $\beta 3$, as well as MMP-2 and -9 were apparently lower than those in the untreated groups (Fig. 4B).

\section{Discussion}

In recent years, a number of pre-clinical research studies have suggested that heparin and its pharmacokinetically improved version, LMWH, possess an array of potential anticancer properties in addition to their traditional anticoagulant activities $(17,18)$. Previous studies showed that heparin and LMWH have effective anti-angiogenetic and anti-proliferative activity (19). Apart from anti-angiogenesis and anti-proliferation, the effect of LMWH on tumor metastasis was discovered (20). The findings of certain studies suggest that the action of antimetastasis of LMWH is mediated by inhibiting selectin, which is associated with platelet tumor cell thrombus formation $(21,22)$. However, the action of LMWH on the invasion and metastasis of human A549 lung cancer cells and the possible mechanism have yet to be addressed.

Results of our study showed that Fraxiparine did not change cell viability, cell cycle progression and the apoptotic status of A549 cells. However, it significantly inhibited the invasion, migration and adhesion of A549 cells. It was also found that Fraxiparine markedly caused the up-regulation of the expression of $\mathrm{nm} 23-\mathrm{H} 1$ and the down-regulation of the expression of the heparanase gene at the mRNA level. Furthermore, our results demonstrated that Fraxiparine decreased the expression of integrin $\beta 1$ and $\beta 3$, as well as MMP- 2 and -9 of A549 cells at the mRNA and protein levels. The data strongly suggest that the changes in cell invasion, migration and adhesion status induced by Fraxiparine in A549 cells are related to the expression levels of $\mathrm{nm} 23-\mathrm{H} 1$, heparanase, integrin $\beta 1$ and $\beta 3$, and MMP-2 and -9 .

Heparanase is an endoglycosidase that degrades heparin sulfate on the cell surface and extracellular matrix (ECM).
Heparanase expression is rare in normal tissues, but becomes evident in many human tumors where it significantly increases the angiogenic and metastatic potential of tumor cells $(23,24)$. It has been reported that the inhibition of the transcription of the heparanase gene or the enzyme activity suppresses metastasis formation, indicating that heparanase is involved in the extravasation and invasion processes of cancer $(25,26)$. As a highly specific anti-metastatic target of MMP-2 that plays a significant role in tumor metastasis for anticancer therapy, the change in the heparanase expression regulates MMP-2 expression (27). In addition, it has been reported that a number of LMWHs inhibit the enzymatic activity of heparanase (19). Our result showed that inhibition of the heparanase gene expression by Fraxiparine was significant even with a concentration as low as $20 \mathrm{IU} / \mathrm{ml}$. The inhibition rate reached $81 \%$. The result was consistent with previous studies and demonstrated a direct effect of heparanase on tumor cell invasion and metastasis in vitro.

$\mathrm{nm} 23-\mathrm{H} 1$, a tumor metastasis suppressor gene, was first identified by the differential screening of melanoma cell lines with a high and low metastatic potential (28). A low expression of $\mathrm{nm} 23-\mathrm{H} 1$ leads to metastasis formation in lung cancer (29). Multiple transfection experiments indicate that, when $\mathrm{nm} 23-\mathrm{H} 1$ expression is forcibly restored, metastases to the lungs, lymph nodes and other organs significantly decreased (30). On the other hand, evidence indicates that the MMPs are down-regulated in cells expressing relatively higher levels of nm23-H1 (31). The molecular mechanism of $\mathrm{nm} 23-\mathrm{H} 1$ in suppressing lung cancer invasion and metastasis may be through the regulation of the differential expression of a series of tumor metastasis-associated genes. Findings of this study found that the RNA expression level of nm23-H1 in A549 cells treated with Fraxiparine increased approximately 2 -fold compared to the untreated cells. This result suggests that the mechanism of Fraxiparine in the inhibition of the invasion and metastasis of A549 cells occurs through the regulation of nm23-H1-mediated signaling pathways or tumor metastasis-associated genes.

To further explore the potential mechanisms of Fraxiparine on the invasion and metastasis of A549 cells, the change in expression of various invasion and metastasis molecules such as the integrins and members of the MMP family using RT-PCR and Western blotting were examined. Integrins and MMPs play a significant role in the invasion and metastasis of cancer. Integrins are the primary receptors for cellular adhesion to ECM molecules. They act as crucial transducers of bidirectional cell signaling, regulate cell survival, adhesion, invasion, differentiation, proliferation, migration and tissue remodeling (32-34). However, the effect of Fraxiparine on integrin expression in lung cancer cells has yet to be determined. Fraxiparine was found to down-regulate the mRNA and protein expression of integrin $\beta 1$ and $\beta 3$ in A549 cells and decrease the migration rate of A549 cells.

MMPs are a multigene family of zinc-dependent endopeptidases that play a significant role in ECM degradation for tumor growth, invasion and tumor-induced angiogenesis. Among the MMPs, MMP-2 and -9 play the most important role in basement membrane type IV collagen degradation $(35,36)$. However, no report exists on the inhibition of LMWH on MMPs in lung cancer cells. This study found that Fraxiparine 
decreased the expression of MMP-2 and -9 in A549 cells at the mRNA and protein levels. This decrease may account for the inhibitory effects of Fraxiparine on the invasion and migration of A549 cells.

The group of LMWHs contains different molecules such as dalteparin, enoxaparin, nadroparin, certoparin and tinzaparin. Each molecule has a slight difference in its chemical structure compared to the remaining molecules (37). Besides their similar anticoagulant effects, they may exert differential biological activities (38). To our knowledge, this is the first report on the inhibitory effects and the mechanism of Fraxiparine on the invasion and metastasis of A549 cells. Fraxiparine did not significantly affect cell viability, cell cycle progression and the apoptotic status of A549 cells. The molecular mechanism of Fraxiparine against the invasion and metastasis of A549 cells may be related to $\mathrm{nm} 23-\mathrm{H} 1$ and heparanase genes and further mediated through the down-regulation of integrin $\beta 1$ and $\beta 3$, as well as MMP-2 and -9. Our results therefore suggest the potential of Fraxiparine for the treatment of lung cancer metastasis. However, further studies are required to confirm these results.

\section{Acknowledgements}

This study was supported by a grant from the National Key Research Project for New Drug Development of China (2009ZX09301-004).

\section{References}

1. Jemal A, Murray T, Ward E, Samuels A, Tiwari RC, Ghafoor A, Feuer EJ and Thun MJ: Cancer statistics. CA Cancer J Clin 55: 10-30, 2005

2. Rabenstein DL: Heparin and heparan sulfate: structure and function. Nat Prod Rep 19: 312-331, 2002.

3. Hirsh J, Warkentin TE, Shaughnessy SG, Anand SS, Halperin JL, Raschke R, Granger C, Ohman EM and Dalen JE: Heparin and low-molecular-weight heparin: mechanisms of action, pharmacokinetics, dosing, monitoring, efficacy and safety. Chest 119: S64-S94, 2001.

4. Akl EA, Rohilla S, Barba M, Sperati F, Terrenato I, Muti P, Bdair F and Schünemann HJ: Anticoagulation for the initial treatment of venous thromboembolism in patients with cancer: a systematic review. Cancer 113: 1685-1694, 2008.

5. Robert F, Busby E, Marques MB, Reynolds RE and Carey DE: Phase II study of docetaxel plus enoxaparin in chemotherapynaive patients with metastatic non-small cell lung cancer: preliminary results. Lung Cancer 42: 237-245, 2003.

6. Altinbas M, Coskun HS, Er M, Ozkan O, Eser B, Unal A, Cetin M and Soyuer S: A randomized clinical trial of combination chemotherapy with and without low-molecular-weight heparin in small cell lung cancer. J Thromb Haemost 2: 1266-1271, 2004.

7. Akl EA, van Doormaal FF, Barba M, Kamath G, Kim SY, Kuipers S, Middeldorp S, Yosuico V, Dickinson HO and Schünemann HJ: Parenteral anticoagulation may prolong the survival of patients with limited small cell lung cancer: a Cochrane systematic review. J Exp Clin Cancer Res 27: 4, 2008.

8. Von Tempelhoff GF, Harenberg J, Niemann F, Hommel G, Kirkpatrick CJ and Heilmann L: Effect of low molecular weight heparin (Certoparin) versus unfractionated heparin on cancer survival following breast and pelvic cancer surgery: A prospective randomized double-blind trial. Int J Oncol 16: 815-824, 2000.

9. Nagy Z, Turcsik V and Blaskó G: The effect of LMWH (Nadroparin) on tumor progression. Pathol Oncol Res 15: 689-692, 2009.

10. Constantini S, Kanner A, Friedman A, Shoshan Y, Israel Z, Ashkenazi E, Gertel M, Even A, Shevach Y, Shalit M, Umansky F and Rappaport ZH: Safety of perioperative minidose heparin in patients undergoing brain tumor surgery: a prospective, randomized double-blind study. J Neurosurg 94: 918-921, 2001.
11. Kakkar AK, Levine MN, Kadziola Z, Lemoine NR, Low V, Patel HK, Rustin G, Thomas M, Quigley M and Williamson RC: Low molecular weight heparin, therapy with dalteparin, and survival in advanced cancer: the Fragmin Advanced Malignancy Outcome Study (FAMOUS). J Clin Oncol 22: 1944-1948, 2004.

12. Klerk CP, Smorenburg SM, Otten HM, Lensing AW, Prins MH, Piovella F, Prandoni P, Bos MM, Richel DJ, van Tienhoven G and Büller HR: The effect of low molecular weight heparin on survival in patients with advanced malignancy. J Clin Oncol 23: 2130-2135, 2005.

13. Kuderer NM, Ortel TL and Francis CW: Impact of venous thromboembolism and anticoagulation on cancer and cancer survival. J Clin Oncol 27: 4902-4911, 2009.

14. Kragh M, Binderup L, Vig Hjarnaa PJ, Bramm E, Johansen KB and Frimundt Petersen C: Non-anti-coagulant heparin inhibits metastasis but not primary tumor growth. Oncol Rep 14: 99-104, 2005.

15. Ludwig RJ, Boehme B, Podda M, Henschler R, Jager E, Tandi C, Boehncke WH, Zollner TM, Kaufmann R and Gille J: Endothelial P-selectin as a target of heparin action in experimental melanoma lung metastasis. Cancer Res 64: 2743-2750, 2004.

16. Mellor P, Harvey JR, Murphy KJ, Pye D, O'Boyle G, Lennard TWJ, Kirby JA and Ali S: Modulatory effects of heparin and short-length oligosaccharides of heparin on the metastasis and growth of LMD MDA-MB 231 breast cancer cells in vivo. Br J Cancer 97: 761-768, 2007.

17. Smorenburg SM, Vink R, Otten HM, Swaneveld F and Büller HR: The effects of vitamin $\mathrm{K}$ antagonists on survival of patients with malignancy: a systematic analysis. Thromb Haemost 86: 1586-1587, 2001.

18. Niers TM, Klerk CP, DiNisio M, van Noorden CJ, Büller HR, Reitsma PH and Richel DJ: Mechanisms of heparin-induced anti-cancer activity in experimental cancer models. Crit Rev Oncol Hematol 61: 195-207, 2007.

19. Takahashi H, Ebihara S, Okazaki T and Yamaya M: A comparison of the effects of unfractionated heparin, dalteparin and danaparoid on vascular endothelial growth factor-induced tumor angiogenesis and heparanase activity. $\mathrm{Br} \mathrm{J}$ Pharmacol 146: 333-343, 2005.

20. Mousa SA and Petersen LJ: Anti-cancer properties of low-molecular-weight heparin: preclinical evidence. Thromb Haemost 102: 258-267, 2009.

21. Hostettler N, Naggi A, Torri G, Ishai-Michaeli R, Casu B, Vlodavsky I and Borsig L: P-selectin- and heparanase-dependent antimetastatic activity of non-anticoagulant heparins. FASEB J 21: 3562-3572, 2007

22. Stevenson JL, Choi SH and Varki A: Differential metastasis inhibition by clinically relevant levels of heparins - correlation with selectin inhibition, not antithrombotic activity. Clin Cancer Res 11: 7003-7011, 2005.

23. Vlodavsky I, Goldshmidt O,ZchariaE, Atzmon R, Rangini-GuattaZ, Elkin M, Peretz T and Friedmann Y: Mammalian heparanase: involvement in cancer metastasis, angiogenesis and normal development. Semin Cancer Biol 12: 121-129, 2002.

24. Sasaki M, Ito T, Kashima M and Miura M: Erythromycin and clarithromycin modulation of growth factor-induced expression of heparanase mRNA on human lung cancer cells in vitro. Mediators Inflamm 10: 259-267, 2001.

25. Edovitsky E, Elkin M, Zcharia E, Peretz T and Vlodavsky I: Heparanase gene silencing, tumor invasiveness, angiogenesis, and metastasis. J Natl Cancer Inst 96: 1219-1230, 2004.

26. Joyce JA, Freeman C, Meyer-Morse N, Parish CR and Hanahan D: A functional heparan sulfate mimetic implicates both heparanase and heparan sulfate in tumor angiogenesis and invasion in a mouse model of multistage cancer. Oncogene 24: 4037-4051, 2005.

27. Uno F, Fujiwara T, Takata Y, Ohtani S, Katsuda K, Takaoka M, Ohkawa T, Naomoto Y, Nakajima M and Tanaka N: Antisensemediated suppression of human heparanase gene expression inhibits pleural dissemination of human cancer cells. Cancer Res 61: 7855-7860, 2001

28. Steeg PS, Bevilacqua G, Kopper L, Thorgeirsson UP, Talmadge JE, Liotta LA and Sobel ME: Evidence for a novel gene associated with low tumor metastatic potential. J Natl Cancer Inst 80: 200-204, 1988.

29. Kawakubo Y, Sato Y, Koh T, Kono H and Kameya T: Expression of $\mathrm{nm} 23$ protein in pulmonary adenocarcinomas: inverse correlation to tumor progression. Lung Cancer 17: 103-113, 1997. 
30. Steeg PS, Ouatas T, Halverson D, Palmieri D and Salerno M Metastasis suppressor genes: basic biology and potential clinical use. Clin Breast Cancer 4: 51-62, 2003.

31. Ma W, Chen J, Xue X, Wang Z, Liu H, Wang T, Bai Y, Tang SC and Zhou Q: Alteration in gene expression profile and biological behavior in human lung cancer cell line NL9980 by nm23-H1 gene silencing. Biochem Biophys Res Commun 371: 425-430, 2008.

32. Humphries MJ: Integrin structure. Biochem Soc Trans 28: 311-339, 2000.

33. Giancotti FG and Ruoslahti E: Integrin signaling. Science 285: 1028-1032, 1999.

34. Miranti CK and Brugge JS: Sensing the environment: a historical perspective on integrin signal transduction. Nat Cell Biol 4: E83-E90, 2002.

35. Westermarck J and Kähäri VM: Regulation of matrix metalloproteinase expression in tumor invasion. FASEB J 13: 781-792, 1999.
36. Zeng ZS, Cohen AM and Guillem JG: Loss of basement membrane type IV collagen is associated with increased expression of metalloproteinases 2 and 9 (MMP-2 and MMP-9) during human colorectal tumorigenesis. Carcinogenesis 20: 749-755, 1999.

37. Fareed J, Leong WL, Hoppensteadt DA, Jeske WP, Walenga J, Wahi R and Bick RL: Generic low-molecular-weight heparins: some practical considerations. Semin Thromb Hemost 30: 703-713, 2004.

38. Deepa PR and Varalakshmi P: The cytoprotective role of a lowmolecular-weight heparin fragment studied in an experimental model of glomerulotoxicity. Eur J Pharmacol 478: 199-205, 2003. 